\title{
Species composition and natural infectivity of anthropophilic Anopheles (Diptera: Culicidae) in the states of Córdoba and Antioquia, Northwestern Colombia
}

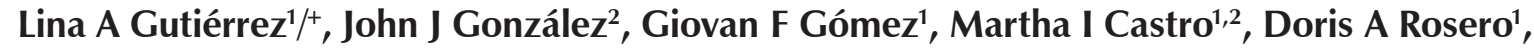 \\ Shirley Luckhart ${ }^{3}$, Jan E Conn ${ }^{4}$, Margarita M Correa ${ }^{1}$ \\ ${ }^{1}$ Grupo de Microbiología Molecular, Escuela de Microbiología, Universidad de Antioquia, Calle 67 53-108, 5-430 Medellín, Colom- \\ bia ${ }^{2}$ Unidad de Entomología, Laboratorio de Salud Pública, Secretaría de Salud Departamental de Córdoba, Montería, Colombia \\ ${ }^{3}$ Department of Medical Microbiology and Immunology, University of California at Davis, California, USA ${ }^{4}$ Griffin Laboratory, Wadsworth \\ Center, New York State Department of Health, New York, USA
}

Malaria is a serious health problem in the states of Córdoba and Antioquia, Northwestern Colombia, where 64.4\% of total Colombian cases were reported in 2007. Because little entomological information is available in this region, the aim of this work was to identify the Anopheles species composition and natural infectivity of mosquitoes distributed in seven localities with highest malaria transmission. A total of 1,768 Anopheles mosquitoes were collected using human landing catches from March 2007-July 2008. Ten species were identified; overall, Anopheles nuneztovari s.l. was the most widespread (62\%) and showed the highest average human biting rates. There were six other species of the Nyssorhynchus subgenus: Anopheles albimanus (11.6\%), Anopheles darlingi (9.8\%), Anopheles braziliensis (6.6\%), Anopheles triannulatus s.l. (3.5\%), Anopheles albitarsis s.l. and Anopheles oswaldoi s.l. at < 1\%; and three of the Anopheles subgenus: Anopheles punctimacula, Anopheles pseudopunctipennis s.l. and Anopheles neomaculipalpus at $<1 \%$ each. Two species from Córdoba, An. nuneztovari and An. darlingi, were found to be naturally infected by Plasmodium vivax VK247, as determined by ELISA and confirmed by nested PCR. All species were active indoors and outdoors. These results provide basic information for targeted vector control strategies in these localities.

Key words: malaria - Anopheles - biting activity - natural infectivity - Northwestern Colombia

Malaria remains an important public health problem in Colombia. Of the 110,480 malaria cases reported in 2007 by the Colombian National Institute of Health, 31.9\% were from Córdoba and 32.5\% from Antioquia. These regions report significant numbers of autochthonous malaria cases, particularly those caused by Plasmodium vivax Grassi \& Felleti (INS 2007).

It is a challenge to determine all of the factors involved in the dynamics of malaria transmission in a given geographic area. However, knowledge about the presence, distribution and abundance of anopheline vector species is critical to facilitate development of efficient vector control policies (Loaiza et al. 2008). Initial efforts to describe Anopheles species distribution in Colombia were conducted by the Servicio de Erradicacion de la Malaria (SEM) more than 50 years ago. These studies reported 16 Anopheles species from Antioquia and 11 species from Córdoba (SEM 1957). A recent review of Anopheles species distribution in Colombia

Financial support: CODI-Universidad de Antioquia (8700-039 and E-01233 to MMC), US-NIH (R03AI076710 to MMC), Instituto Colombiano para el Desarrollo de la Ciencia y la Tecnología Francisco José de Caldas, COLCIENCIAS (to LAG for doctoral training)

+ Corresponding author: liangutibui@gmail.com

Received 7 July 2009

Accepted 3 November 2009
(González \& Carrejo 2007), which included SEM reports and data gathered from scientific papers, showed a high diversity of Anopheles species in both states: Anopheles albimanus Wiedemann, Anopheles apicimacula Dyar \& Knab, Anopheles argyritarsis Robineau-Desvoidy, Anopheles braziliensis (Chagas), Anopheles costai Fonseca \& Ramos, Anopheles darlingi Root, Anopheles eiseni Coquillett, Anopheles marajoara Galvão \& Damasceno, Anopheles neomaculipalpus Curry, Anopheles nuneztovari Gabaldon, Anopheles oswaldoi (Peryassu), Anopheles pseudopunctipennis Theobald, Anopheles punctimacula Dyar \& Knab, Anopheles rangeli Gabaldon, Cova Garcia \& Lopez, Anopheles strodei Root and Anopheles triannulatus Neiva \& Pinto. Anopheles malefactor Dyar \& Knab and Anopheles neivai Howard Dyar \& Knab were reported only in Antioquia and Anopheles aquasalis Curry only in Córdoba. Several of these species, including An. albimanus, An. darlingi and An. nuneztovari s.l., are primary malaria vectors in other regions of Colombia and An. rangeli, An. oswaldoi s.l., An. neivai and An. marajoara are of regional/local importance (Herrera et al. 1987, Olano et al. 2001, Quiñones et al. 2006, Gutiérrez et al. 2008).

Morphological and molecular studies have demonstrated high levels of intra-individual variation and inter-specific similarities in Anopheles (Harbach 2004, Marrelli et al. 2005, Li \& Wilkerson 2007, Calle et al. 2008). In Colombia, the geographical distribution of members of species complexes and their potential role(s) in malaria transmission are poorly understood. 
Examples include the Albitarsis Complex (Wilkerson et al. 1995, Lehr et al. 2005), An. triannulatus s.l. (SilvaDo-Nascimento et al. 2006), An. nuneztovari s.l. (Kitzmiller et al. 1973, Conn et al. 1998, Mirabello \& Conn 2008) and An. pseudopunctipennis s.l., a recognised malaria vector in Mexico (Rodriguez et al. 2000, Joy et al. 2008), Bolivia (Lardeux et al. 2007) and Argentina (Dantur Juri et al. 2009). It is important to clarify the role that Anopheles species from Córdoba and Antioquia have in malaria transmission because primary malaria vectors may coexist with other species that are potential vectors or vectors of regional/local importance (Moreno et al. 2005, Póvoa et al. 2006, Quiñones et al. 2006, Gutiérrez et al. 2008). It has been observed that species distribution and behaviour can vary temporally in relation to climate variations (Tadei et al. 1998, Gevrey \& Worner 2006) and furthermore, recent studies suggest that geographic and climatic variation, in addition to the cultural diversity observed in endemic regions of Colombia, may affect malaria transmission (Poveda et al. 2001, Mantilla et al. 2009). The aim of this study was to provide current information on anopheline species geographical distribution and detection of mosquitoes naturally infected with Plasmodium falciparum Welch and $P$. vivax, VK210 and VK247 collected in close proximity to humans in various localities within Antioquia and Córdoba. This paper provides a revision of anthropophilic Anopheles species composition, feeding behaviour and vector incrimination through the evaluation of indoor and peri-domestic areas in these localities.

\section{MATERIALS AND METHODS}

Study sites - Anopheles mosquitoes were collected in localities from the states of Córdoba and Antioquia (departments), Northwestern Colombia. Both states include areas in the Caribbean and the Andean Regions, which correspond to Coastal and Piedmont ecoregions, respectively, according to the classification of Rubio-Palis and Zimmerman (1997). These areas are characterised by diverse flora and wildlife, which are influenced by the contrasting topographies and temperature variations. The sites had temperatures up to $26^{\circ} \mathrm{C}$ and relative humidity $>80 \%$ (IGAC 2002). Localities with the highest official malaria reports from each state were selected for this study and included in Antioquia: Turbo (TUR; $8^{\circ} 05^{\prime} \mathrm{N}, 76^{\circ} 44^{\prime} \mathrm{W}$ ), Zaragoza (ZAR; $7^{\circ} 29^{\prime} \mathrm{N}, 74^{\circ} 51^{\prime} \mathrm{W}$ ) and El Bagre (BAG; $7^{\circ} 35^{\prime} \mathrm{N}$, 74² $49^{\prime} \mathrm{W}$ ); these localities represented $36 \%$ of the total cases reported for Antioquia (DSSA 2008). In Córdoba, the localities sampled were: Valencia (VAL; $8^{\circ} 15^{\prime} \mathrm{N}, 76^{\circ} 08^{\prime} \mathrm{W}$ ), Tierralta (TAL; $8^{\circ} 10^{\prime} \mathrm{N}, 7^{\circ} 03^{\prime} \mathrm{W}$ ), Puerto Libertador (PLT; 7 ${ }^{\circ} 54^{\prime} \mathrm{N}$, $75^{\circ} 40^{\prime} \mathrm{W}$ ) and Montelibano (MTL; 759'N, $75^{\circ} 25^{\prime} \mathrm{W}$ ) (Figure); these localities represented $97.85 \%$ of the total cases for Córdoba (Gobernación de Córdoba 2008).

The main economic activities in VAL, TAL, MTL and PLT (Córdoba) and TUR (Antioquia) are crop and livestock production, while in BAG and ZAR (Antioquia), alluvial mining, followed by livestock, sorghum and rice production are the most important economic activities. In this study, most field visits could not be planned according to seasonal or tempo- ral climatic changes. Rather, collections were based on accessibility to the localities and on confirmation of local security.

Mosquito collection and species identification The collection of adult mosquitoes by human-landing catches (HLC) were conducted under an informed consent agreement using a protocol and collection procedures that were reviewed and approved by a University of Antioquia Institutional Review Board. Indoor and peri-domestic collections (within $\sim 5 \mathrm{~m}$ of each house) were performed from 18-22 $\mathrm{h} \pm 2 \mathrm{~h}$, between March 2007-July 2008. At least one collection per field trip was conducted overnight (18-6 h) in TAL, PLT, MTL and TUR. Collections were conducted in most cases by at least three human baits per shift. In addition, larval habitats were visited for collection at one location in each state, ZAR and MTL. For some species it was possible to obtain and rear field-collected larvae to support species identification. Adult mosquitoes and immature stages available (larvae, pupae or their exuviae) were identified based on morphological features according to the taxonomic key by Gonzalez and Carrejo (2007). Because mis-assignments occur often among species in the Oswaldoi Group of Nyssorhynchus based on morphological characteristics (Ruiz et al. 2005), we verified species assignation for all the Oswaldoi Group specimens using a PCR-RFLP assay based on ITS2 sequences (Zapata et al. 2007, Cienfuegos et al. 2008). The DNA was obtained from a single leg added to a PCR mixture or genomic DNA obtained from individual abdomens. In addition, some of the mosquitoes identified as An. albimanus or An. darlingi were selected at random and their species assignment was molecularly confirmed using the PCR-RFLP-ITS2 assay (Zapata et al. 2007).

Natural infectivity status - Natural infectivity by $P$. falciparum and P. vivax (VK210 and VK247) was evaluated using a standard ELISA protocol (Wirtz et al. 1987a, b, 1991, 1992) on pooled heads and thoraces

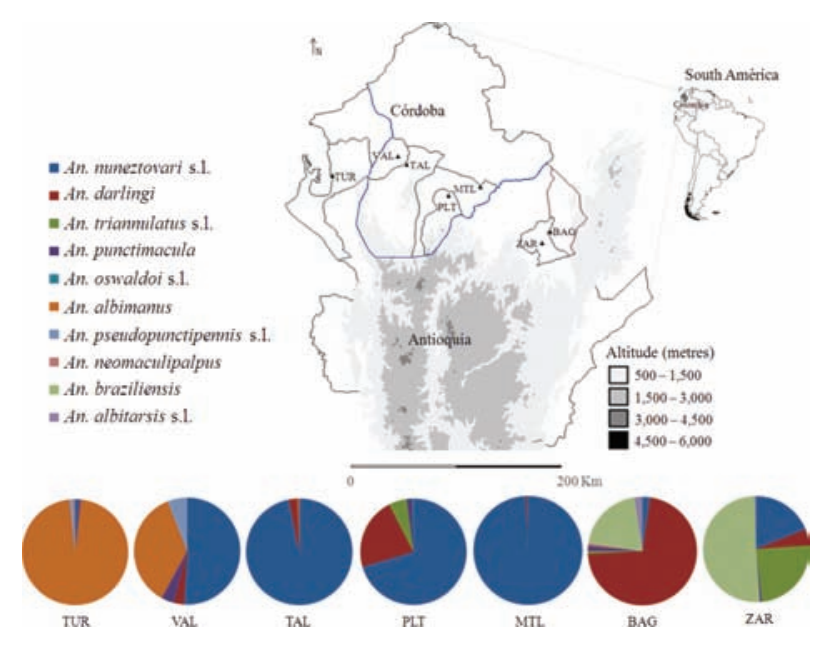

Distribution of specimens and collection localities in states of Antioquia and Córdoba, Colombia. 
of five mosquitoes of the same species. To perform the ELISA assays, pools were macerated in $50 \mu \mathrm{L}$ BB-IGEPAL buffer and the volume adjusted to $250 \mu \mathrm{L}$ with BB buffer. Positive ELISA pools were analysed by nested genus-specific PCR (Singh et al. 1999) on individual mosquito abdomens to determine the specific infected mosquito within each pool.

Data analysis - Descriptive statistics were performed using GraphPad Prism version 4.00 (GraphPad 1992-2003) and $p<0.05$ as the cut-off for statistical significance. Infectivity rate (IR) for each species was expressed as the number of positive individuals (np) per number of total analysed (nt) per 100 determined per site and per state [IR $=(\mathrm{np} / \mathrm{nt}) \mathrm{x}$ 100]. In addition, the confidence interval (CI 95\%) was calculated to indicate the reliability of the estimated value, under the assumption of a binomial distribution, using the EPIDAT program, version 3.1 (OPS/OMS 2006). Human-biting activity was registered directly from HLCs. Hourly data from all collections were grouped and the total number of bites per hour was obtained for each species by site. Overall averages of the human-biting rate (HBR) were estimated from HLCs for each species. These data were expressed as the number of bites per person per night $(\mathrm{b} / \mathrm{p} / \mathrm{n})$ during nights with $6 \mathrm{~h}$ collections and nights with $12 \mathrm{~h}$ collections. Values of HBR per species, per site (log transformed) were tested for differences among species using one-way ANOVA.

\section{RESULTS}

Species composition and identification of anthropophilic anophelines - A total of 1,768 Anopheles mosquitoes were collected by HLC at seven localities from Córdoba and Antioquia, during 24 field trips and approximately $480 \mathrm{~h}$ of sampling, with each site visited at least twice. Ten Anopheles species of two subgenera: Nyssorhynchus (7 species) and Anopheles (3 species) were identified. Collection dates and sample sizes are shown in Table I. As expected, most morphological misidentifications occurred among the Oswaldoi Group. In particular, An. nuneztovari s.l., An. oswaldoi s.l. and An. rangeli were confirmed by PCR-RFLP-ITS2 assays performed on individual adults (Zapata et al. 2007, Cienfuegos et al. 2008). Immature stages and male genitalia (when available) were also used to confirm adult identification. Immature stages were identified for $A n$. nuneztovari s.l. $(\mathrm{n}=3)$, An. triannulatus s.l. $(\mathrm{n}=1)$ and An. albitarsis s.l. $(\mathrm{n}=1)$ from MTL in Córdoba, collected from sunlit flooded pasture fields and also for An. nuneztovari s.l. $(\mathrm{n}=2)$, An. triannulatus s.l. $(\mathrm{n}=$ 5) and An. braziliensis $(n=1)$, collected from mining excavations, with partial light exposure, from BAG and ZAR in Antioquia. Anthropophilic species composition by locality, as determined by morphological and molecular tests, is illustrated in Figure and Table I.

A total of 1,201 specimens were identified from Córdoba. An. nuneztovari s.l. and An. darlingi were found in all localities, but An. nuneztovari s.l. was the predominant species, corresponding to $88 \%$ of the total specimens identified. An. darlingi accounted for $6 \%$, with the highest density in PLT. Five other species represented $6 \%$ of the identified specimens and were distributed as follows: An. punctimacula was found in VAL, PLT and MTL, An. pseudopunctipennis s.l. in VAL, An. albimanus was the second most abundant species in VAL and it was also found in TAL, An. triannulatus s.l. in PLT and An. oswaldoi s.l. in PLT and MTL. In Antioquia, 482 specimens were identified and the predominant species was different in each locality. In TUR, An. albimanus was the most abundant species (96.6\%); four other species were present at $\leq 1.1 \%$ : An. nuneztovari s.l., An. pseudopunctipennis s.l., An. punctimacula and An. neomaculipalpus. In ZAR, the most predominant species, in order of abundance, were $A n$. braziliensis, An. triannulatus s.l. and An. nuneztovari s.l., with An. darlingi (5\%), An. punctimacula and An. albitarsis s.l. each present at $<1 \%$. In BAG, the most common species were An. darlingi and An. braziliensis, with An. nuneztovari s.l., An. triannulatus s.l., An. punctimacula, An. neomaculipalpus and An. albitarsis s.l. each present at less than $2.5 \%$.

Anopheles species naturally infected with Plasmodium - To determine the natural infectivity of Anopheles species collected in Córdoba and Antioquia, 1,616 specimens corresponding to 463 pools with up to five individuals per pool were analysed by ELISA (Table II). No species collected from Antioquia was infected. In contrast, two species collected in Córdoba, An. nuneztovari s.l. and An. darlingi, were found naturally infected. Of 1,047 An. nuneztovari s.l. tested, four individuals were found infected with $P$. vivax VK247 which represented a total IR for this species in Córdoba of 0.382\% (CI: 0.1040.975); three individuals were from MTL, representing an IR of $0.489 \%$ (3/613; CI: 0.101-1.424) for this locality and the other An. nuneztovari s.l. was from TAL, corresponding to an IR of $0.649 \%$ (1/154; CI: 0.016-3.565). From a total of 166 An. darlingi analysed, one individual from PLT was found infected with P. vivax VK247, resulting in an IR of 1.587\% (1/63; CI: 0.040-8.530) for this locality and 1.449\% (1/69; CI: 0.037-7.812) for Córdoba. No specimens were ELISA-positive for $P$. falciparum. The genus-specific nested PCR confirmed the infectivity of five individual Plasmodium-infected mosquitoes that were ELISA-positive for P. vivax VK247.

All species collected registered biting activity both indoors and outdoors. Four of the five infected specimens were caught indoors, one An. darlingi from PLT, one An. nuneztovari s.l. from TAL and two from MTL; only one infected An. nuneztovari s.l. was caught outdoors, at midnight, from MTL. An. nuneztovari s.l. and An. darlingi showed biting activity throughout the night, mainly between 19-3 h. No An. nuneztovari s.l. specimens from PLT were found to be infected; however, this species was the most prevalent and showed the highest HBR in all field trips (data not shown). Overall HBR means were not significantly different among mosquito species $(\mathrm{F}=0.3684 ; \mathrm{p}=0.8963)$. The greatest HBR were obtained for An. nuneztovari s.l. and for An. albimanus. The highest HBR for An. nuneztovari s.l. was recorded from MTL in Córdoba (2.3 b/p/n) and for An. albimanus from TUR in Antioquia (1.7 b/p/n). 
TABLE I

Anopheles species composition in seven localities of states of Córdoba and Antioquia, Colombia, March 2007-July 2008

\begin{tabular}{|c|c|c|c|c|c|}
\hline Locality & Year & $\begin{array}{c}\text { Month } \\
\text { (number of days) }\end{array}$ & $\begin{array}{c}\text { Anopheles collected } \\
\mathrm{n}\end{array}$ & $\begin{array}{l}\text { Predominant species } \\
\text { (\%) }\end{array}$ & $\begin{array}{l}\text { Other species } \\
\qquad \%)\end{array}$ \\
\hline \multirow[t]{2}{*}{ VAL } & \multirow[t]{2}{*}{2007} & March (1) & \multirow[t]{2}{*}{105} & \multicolumn{2}{|c|}{ Anopheles nuneztovari s.l. (51) Anopheles pseudopunctipennis s.l. (6) } \\
\hline & & April (3) & & Anopheles albimanus (36) & $\begin{array}{l}\text { Anopheles punctimacula (4) } \\
\text { Anopheles darlingi (3) }\end{array}$ \\
\hline \multirow[t]{4}{*}{$\mathrm{TAL}^{a}$} & \multirow[t]{4}{*}{2007} & July (4) & \multirow[t]{4}{*}{193} & \multirow[t]{4}{*}{ An. nuneztovari s.l. (96.5) } & An. darlingi (2.5) \\
\hline & & August (3) & & & An. albimanus (0.6) \\
\hline & & September (2) & & & \\
\hline & & October (1) & & & \\
\hline \multirow[t]{6}{*}{$\mathrm{PLT}^{a}$} & \multirow[t]{6}{*}{2007} & July (3) & \multirow[t]{6}{*}{340} & \multirow{6}{*}{$\begin{array}{c}\text { An. nuneztovari s.l. (70.4) } \\
\text { An. darlingi (22) }\end{array}$} & Anopheles triannulatus s.l. (5.5) \\
\hline & & August (3) & & & An. punctimacula (1.7) \\
\hline & & September (3) & & & Anopheles oswaldoi s.l. (0.3) \\
\hline & & October (2) & & & \\
\hline & & November (2) & & & \\
\hline & & December (2) & & & \\
\hline \multirow[t]{4}{*}{ MTL $^{a}$} & \multirow[t]{4}{*}{2007} & July (5) & \multirow[t]{4}{*}{648} & \multirow[t]{4}{*}{ An. nuneztovari s.l. (99.4) } & An. darlingi (0.3) \\
\hline & & August (2) & & & An. punctimacula (0.2) \\
\hline & & October (3) & & & An. oswaldoi s.l. (0.2) \\
\hline & & November (2) & & & \\
\hline \multirow[t]{2}{*}{$\mathrm{TUR}^{a}$} & 2007 & November (3) & \multirow[t]{2}{*}{174} & \multirow[t]{2}{*}{ An. albimanus (96.6) } & An. nuneztovari s.l. (1.1) \\
\hline & 2008 & May (1) & & & $\begin{array}{l}\text { An. pseudopunctipennis s.l. (1.1) } \\
\text { An. punctimacula (0.9) } \\
\text { Anopheles neomaculipalpus (0.6) }\end{array}$ \\
\hline \multirow[t]{4}{*}{ ZAR } & \multirow[t]{4}{*}{2008} & January (2) & \multirow[t]{4}{*}{180} & Anopheles braziliensis (50.6) & An. darlingi (5) \\
\hline & & March (4) & & An. triannulatus s.l. (24.4) & An. punctimacula (0.6) \\
\hline & & June (1) & & An. nuneztovari s.l. (18.9) & Anopheles albitarsis s.l. (0.6) \\
\hline & & July (2) & & & \\
\hline \multirow[t]{5}{*}{ BAG } & \multirow[t]{5}{*}{2008} & March (3) & \multirow[t]{5}{*}{128} & An. darlingi (71.9) & An. nuneztovari s.l. (2.3) \\
\hline & & May (3) & & An. braziliensis (20.3) & An. albitarsis s.l. (2.3) \\
\hline & & & & & An. punctimacula (1.6) \\
\hline & & & & & An. triannulatus s.l. (0.8) \\
\hline & & & & & An. neomaculipalpus (0.8) \\
\hline
\end{tabular}

Antioquia: BAG: El Bagre (El Sabalito Sinaí, Guachí, La Bonga and La Sardina); TUR: Turbo (Camerum and Yarumal); ZAR: Zaragoza (El Retiro, San Antonio and San Juan de Pelusa). Córdoba: MTL: Montelibano (Puerto Anchica); PLT: Puerto Libertador (La Bonga); TAL: Tierra Alta (Alto Guarumal); VAL: Valencia (Mieles abajo). $a$ : in average 1-2 collections of adult mosquitoes was made overnight per field trip (18-6 h).

\section{DISCUSSION}

An. nuneztovari s.l. was found in all sites sampled from Córdoba and Antioquia and was the most prevalent species in all sites from Córdoba. In this study, the species composition of anthropophilic anophelines was lower than reported previously in Córdoba and Antioquia (SEM 1957, González \& Carrejo 2007). Four species reported in these municipalities $\sim 50$ years ago, $A n$. apicimacula (in TUR), An. costai (in ZAR and MTL), An. rangeli and An. strodei (in TUR, ZAR, VAL, PLT and MTL), were not found in the present study. Anopheles nuneztovari s.l. is still present in the same sites where it was previously reported, An. albimanus continues to be detected in TUR, TAL and VAL, An. punctimacula in TUR and ZAR, An. triannulatus s.l. and An. braziliensis in ZAR, An. darlingi in ZAR and in all sites in Córdoba, while An. pseudopunctipennis s.l. was collected in TUR and VAL and An. neomaculipalpus in TUR (Figure, Table I). An. marajoara was previously reported in ZAR (González \& Carrejo 2007) and An. albitarsis s.l. was distributed in BAG and ZAR, albeit at a low density. Additional molecular procedures must be conducted to determine which species of the albitarsis complex is/are present in these localities because of their potential importance in malaria transmission in this zone.

The reduced diversity of Anopheles species in these sites compared to previous studies may have resulted from: (i) changes in ecological conditions and human activities (Wolda \& Galindo 1981, Conn et al. 2002, Yasuoka \& Levins 2007, Dantur Juri et al. 2009), (ii) failure 


\section{TABLE II}

Detection of natural infection on Anopheles spp females collected in seven localities of states of Córdoba and Antioquia, Colombia

\begin{tabular}{|c|c|c|c|c|}
\hline $\begin{array}{l}\text { Anopheles species } \\
\text { by subgenera }\end{array}$ & $\begin{array}{l}\text { Number collected } \\
\text { (percent identified of total) }\end{array}$ & $\begin{array}{l}\text { Natural infection analysed } \\
\quad \text { (individuals infected by } \\
\text { Plasmodium vivax VK247) }\end{array}$ & $\begin{array}{c}\mathrm{HBR}^{b} \\
\text { (mean } \pm \mathrm{SE} \text { ) } \\
\text { overall }\end{array}$ & $\begin{array}{c}\mathrm{HBR}^{c} \\
\text { (mean } \pm \mathrm{SE}) \\
\text { overall }\end{array}$ \\
\hline \multicolumn{5}{|l|}{ Nyssorhynchus } \\
\hline Anopheles nuneztovari s.l. & $1,096(62)$ & $1,047(4)$ & $0.816 \pm 0.451$ & $0.527 \pm 0.483$ \\
\hline Anopheles albimanus & $205(11.6)$ & 204 & $0.457 \pm 0.380$ & $0.153 \pm 0.305$ \\
\hline Anopheles darlingi & $174(9.8)$ & $166(1)$ & $0.163 \pm 0.116$ & $0.040 \pm 0.073$ \\
\hline Anopheles braziliensis & $117(6.6)$ & 115 & $0.114 \pm 0.082$ & $e$ \\
\hline Anopheles triannulatus s.l. & $61(3.5)$ & 55 & $0.047 \pm 0.038$ & $0.007 \pm 0.015$ \\
\hline Anopheles albitarsis s.l. & $4(0.2)$ & 4 & $0.006 \pm 0.004$ & $e$ \\
\hline Anopheles oswaldoi s.l. & $2(0.1)$ & 2 & $0.001 \pm 0.001$ & $e$ \\
\hline \multicolumn{5}{|l|}{ Anopheles } \\
\hline Anopheles punctimacula & $14(0.8)$ & 13 & $0.019 \pm 0.008$ & $0.005 \pm 0.006$ \\
\hline Anopheles pseudopunctipennis s.l. & $8(0.5)$ & 8 & $0.014 \pm 0.011$ & $0.007 \pm 0.015$ \\
\hline Anopheles neomaculipalpus & $2(0.1)$ & 2 & $0.004 \pm 0.003$ & $e$ \\
\hline Anopheles spp ${ }^{d}$ & $85(4.8)$ & & & \\
\hline Total (individuals) & 1,768 & 1,616 & - & - \\
\hline
\end{tabular}

$a$ : species with infected specimens as determined by nested PCR of individual abdomens of positive pools; b: average bites per person per night $(\mathrm{b} / \mathrm{p} / \mathrm{h})$ obtained from a mean of three collectors between 4-9 d/6h per day replicates for all sites; $c$ : average $\mathrm{b} / \mathrm{p} / \mathrm{n}$ obtained from a mean of three collectors between 10-15 d/12h per day replicates for all sites; $d$ : specimens too damaged to identify; $e$ : specimens not collected; HBR: human-biting rate.

to detect higher species diversity because of differences in the sites sampled/localities, (iii) low and sporadic number of observations and (iv) our use of molecular tools to support species assignments, eliminating previous inaccuracies in species identification. Initially, most misidentifications were detected for members of the Oswaldoi Group - An. strodei, Anopheles benarrochi, An. rangeli and An. oswaldoi s.l. - species characterised by high morphological similarities in adult females. The molecular patterns for those specimens corresponded to An. nuneztovari s.l., a species that is also characterised by high intra-specific morphological variability (Ruiz et al. 2005, Calle et al. 2008, Fajardo et al. 2008).

Our collections of An. nuneztovari s.l. and An. pseudopunctipennis s.l. in VAL are consistent with recent reports by Parra-Henao and Alarcon (2008) from four sites in this locality that confirm that An. nuneztovari s.l. is the most prevalent species (91.1\%) with the highest biting activity outdoors, at $21 \mathrm{~h}$ (data not shown). These authors also collected An. pseudopunctipennis s.l. (4\%) and two additional species not detected in our study: An. neomaculipalpus (4.4\%) and Anopheles evansae (0.5\%). In contrast, our data showed that An. albimanus was the second most abundant species and in addition, we found An. punctimacula and An. darlingi in Mieles Abajo, VAL. The differences in the species composition between these studies could derive from differences in sampling sites, times of the year and collection hours.

Anopheles nuneztovari s.l. biting behaviour varied at each site. For example, in TAL this species showed the highest biting frequency indoors at $23 \mathrm{~h}$, while in MTL occurred outdoors at $20 \mathrm{~h}$ and in PLT it was indoors at $22 \mathrm{~h}$ (data not shown). In VAL, the three primary malaria vectors of Colombia co-occurred: An. albimanus, An. darlingi and An. nuneztovari s.l. However, no naturally infected specimens were detected at VAL, probably because of the small sample size (105 specimens) tested. These species are able to transmit the parasites to humans (SEM 1957, Herrera et al. 1987, Gutiérrez et al. 2008) and in this study they showed human-biting activity, both indoors and outdoors, suggesting that further studies should be conducted to determine their role in malaria transmission in VAL.

All species collected in this study were anthropophilic and endo-exophagic. Plasmodium-infected An. darlingi and An. nuneztovari s.l. from PLT and MTL-TAL, respectively, were collected throughout the night (18-6 h), but in general these mosquitoes species were more active between 19-3 h. These data agree with results from longitudinal entomological and epidemiological studies carried out by Moreno et al. (2007) in the Southern Venezuela, where An. darlingi biting activity was evident through the night. In TUR, a Caribbean coast locality, An. albimanus was the predominant species (96.6\%) and exhibited biting activity both indoors and in peri-domestic areas, especially between 18-22 h, with a peak activity indoors at $20 \mathrm{~h}$ (data not shown). Previous work also showed that this species predominated in the Colombian Caribbean region (Gutiérrez et al. 2008).

An. triannulatus s.l. has been traditionally considered zoophilic (Faran \& Linthicum 1981) and it has not been reported to be naturally infected with Plasmodium 
spp in endemic areas of Colombia. In this work, An. triannulatus s.l. showed anthropophilic activity and it was active indoors and outdoors, mainly between 18-1 $\mathrm{h}$ in PLT, ZAR and BAG. Similarly, Brochero et al. (2006) found An. triannulatus s.l. indoors and outdoors in Northeastern Colombia, exhibiting indoor biting activity similar to An. nuneztovari s.l. the main malaria vector. An. triannulatus s.l. constitutes a species complex with differences in malaria transmission ability (Silva-DoNascimento et al. 2006, Galardo et al. 2007); therefore, it will be important to investigate which species of the complex is/are present in these endemic areas and their potential as local vectors.

The overall average HBRs estimated for these species were in the range of values reported for the same species in other areas (Olano et al. 1997, Loaiza et al. 2008). Previous HBRs detected for An. albimanus in Buenaventura (Colombian Pacific region) were 0-7.1 (Olano et al. 1997) and 0.1-3.5 in Isla Pino (Panamá) (Loaiza et al. 2008). Also, HBR values for An. darlingi, An. nuneztovari s.l., An. albitarsis s.l. and An. braziliensis agree with those found in Boa Vista, Roraima, Brazil for the same species (da Silva-Vasconcelos et al. 2002, Póvoa et al. 2006). Specimens of An. darlingi, An. triannulatus s.l., An. oswaldoi s.l., An. braziliensis, An. albitarsis s.l., An. punctimacula and An. pseudopunctipennis s.l. were less abundant and thus HBRs by site for these species were lower than $1 \mathrm{~b} / \mathrm{p} / \mathrm{n}$. Nonetheless, the presence of these species could have important epidemiological implications with respect to malaria transmission because of their high anthropophilic behaviour.

Two species, An. nuneztovari s.l. and An. darlingi, were found to be infected with $P$. vivax VK247 in Córdoba. These two species have been previously identified to be involved in transmission in others areas in Colombia. Reports by SEM (1957) showed that An. darlingi from Northern and Southern Colombia (Barrancabermeja, Santander; Villavicencio, Meta and Rioacha in Guajira) and An. nuneztovari s.l. from Cucuta in state of Norte de Santander were positive for Plasmodium sporozoites in the midgut and salivary glands. Also, Herrera et al. (1987) found An. darlingi infected with P. falciparum in Southwestern Colombia (Puerto Lleras, Meta) at IRs of $0.1 \%$ (indoors) and $0.06 \%$ (outdoors). A recent study that estimated natural IRs in the malaria vectors $A n$. albimanus and An. neivai (Gutiérrez et al. 2008) and the present study implicates An. darlingi and An. nuneztovari s.l. In general, these two studies show that IRs for Colombian Anopheles species are low, but still enough to maintain malaria transmission in these endemic areas (INS 2007, WHO 2008).

Vector control is an important component of malaria control programs because it is one of the most efficient strategies to prevent transmission (WHO 2006). Our study identifies two vector species in Córdoba, Colombia, a highly endemic region. This information contributes to a better knowledge of the species with anthropophilic preferences in these areas. This information could help direct vector management activities in this region.

\section{ACKNOWLEDGMENTS}

To L Córdoba, A Ruiz, Y Berruecos, W Bedoya, J Baquero, A Puerta, R Villalba, who cooperated in specimen collection in the localities included in this study, to the coordinators and staff at Unidad de Entomología, Laboratorio de Salud Pública, Secretaría de Salud Departamental, Córdoba, and to members from Grupo de Microbiología Molecular, for their technical assistance, especially to Luz Marina Jaramillo, Vanessa Cienfuegos and Nelson Naranjo.

\section{REFERENCES}

Brochero H, Pareja PX, Ortiz G, Olano VA 2006. Breeding places and biting activity of Anopheles species in the municipality of Cimitarra, Santander, Colombia. Biomedica 26: 269-277.

Calle DA, Quinones ML, Erazo HF, Jaramillo N 2008. Differentiation by geometric morphometrics among 11 Anopheles (Nyssorhynchus) in Colombia. Biomedica 28: 371-385.

Cienfuegos AV, Gómez GF, Córdoba LA, Luckhart S, Conn JE, Correa MM 2008. Diseño y evaluación de metodologías basadas en PCR-RFLP de ITS2 para la identificación molecular de mosquitos Anopheles spp (Diptera: Culicidae) de la Costa Pacífica de Colombia. Rev Biomed 19: 35-44.

Conn J, Mitchell S, Cockburn A 1998. Mitochondrial DNA analysis of the neotropical malaria vector Anopheles nuneztovari. Genome 41: 313-327.

Conn JE, Wilkerson RC, Segura MN, de Souza RT, Schlichting CD, Wirtz RA, Povoa MM 2002. Emergence of a new neotropical malaria vector facilitated by human migration and changes in land use. Am J Trop Med Hyg 66: 18-22.

da Silva-Vasconcelos A, Kato MY, Mourao EN, de Souza RT, Lacerda RN, Sibajev A, Tsouris P, Povoa MM, Momen H, Rosa-Freitas MG 2002. Biting indices, host-seeking activity and natural infection rates of anopheline species in Boa Vista, Roraima, Brazil from 1996 to 1998. Mem Inst Oswaldo Cruz 97: 151-161.

Dantur Juri MJ, Zaidenberg M, Claps GL, Santana M, Almiron WR 2009. Malaria transmission in two localities in Northwestern Argentina. Malar J 8: 18.

DSSA - Direccion Seccional de Salud de Antioquia 2008. [accessed April, 2009]. Incidencia de malaria total por municipios y regiones. Available from: http://www.dssa.gov.co/htm/inciden.htm.

Fajardo M, González R, Suárez M, López D, Wilkerson R, Sallum M 2008. Morphological analysis of three populations of Anopheles (Nyssorhynchus) nuneztovari Gabaldón (Diptera: Culicidae) from Colombia. Mem Inst Oswaldo Cruz 103: 85-92.

Faran M, Linthicum L 1981. A handbook of the Amazonian species of Anopheles (Nyssorhynchus) (Diptera: Culicidae). Mosq Syst 13: 1-81.

Galardo A, Arruda M, D’almeida A, Wirtz R, Lounibos P, Zimmerman R 2007. Malaria vector incrimination in three rural riverine villages in the Brazilian Amazon. Am J Trop Med Hyg 76: 461-469.

Gevrey M, Worner SP 2006. Prediction of global distribution of insect pest species in relation to climate by using an ecological informatics method. J Econ Entomol 99: 979-986.

Gobernación de Córdoba 2008. Situación epidemiológica del programa de enfermedades transmitidas por vectores. Datos suministrados por la Secretaría de Desarrollo de la Salud, Montería, Córdoba, 19 pp.

González R, Carrejo N 2007. Introducción al estudio taxonómico de Anopheles de Colombia: claves y notas de distribución, Universidad del Valle, Cali, 237 pp. 
GraphPad Prism version 4.00 for Windows ${ }^{\oplus}$ 1992-2003. GraphPad Software Inc San Diego, California, USA.

Gutiérrez LA, Naranjo N, Jaramillo LM, Muskus C, Luckhart S, Conn JE, Correa MM 2008. Natural infectivity of Anopheles species from the Pacific and Atlantic Regions of Colombia. Acta Trop 107: 99-105.

Harbach RE 2004. The classification of genus Anopheles (Diptera: Culicidae): a working hypothesis of phylogenetic relationships. Bull Entomol Res 94: 537-553.

Herrera S, Suarez M, Sanchez G, Quiñones M, Herrera M 1987. Uso de la técnica inmuno-radiométrica (IRMA) en Anopheles de Colombia para la identificación de esporozoitos de Plasmodium. Colomb Med 18: 2-6.

IGAC - Instituto Geográfico Agustín Codazzi 2002. Atlas de Colombia. Publicación Institucional, Imprenta Nacional de Colombia, Bogotá, 342 pp.

INS 2007 - Instituto Nacional de Salud. Boletín Epidemiológico Semanal. Estadísticas del sistema de vigilancia en salud pública - SIVIGILA, Casos totales en la Semana Epidemiológica 52 y acumulados del año, Subdirección de Vigilancia y Control en Salud Pública. Available from: http://www.ins.gov. $\mathrm{co} /$ ?idcategoria $=6003$.

Joy DA, Gonzalez-Ceron L, Carlton JM, Gueye A, Fay M, McCutchan TF, Su XZ 2008. Local adaptation and vector-mediated population structure in Plasmodium vivax malaria. Mol Biol Evol 25: 1245-1252.

Kitzmiller JB, Kreutzer RD, Tallaferro E 1973. Chromosomal differences in populations of Anopheles nuneztovari. Bull World Health Organ 48: 435-445.

Lardeux F, Loayza P, Bouchite B, Chavez T 2007. Host choice and human blood index of Anopheles pseudopunctipennis in a village of the Andean valleys of Bolivia. Malar J 6: 8 .

Lehr MA, Kilpatrick CW, Wilkerson RC, Conn JE 2005. Cryptic species in the Anopheles (Nyssorhynchus) albitarsis (Diptera: Culicidae) complex: incongruence between random amplified polymorphic DNA-polymerase chain reaction identification and analysis of mitochondrial DNA COI gene sequences. Ann Entomol Soc Am 98: 908-917.

Li C, Wilkerson RC 2007. Intragenomic rDNA ITS2 variation in the neotropical Anopheles (Nyssorhynchus) albitarsis complex (Diptera: Culicidae). J Hered 98: 51-59.

Loaiza JR, Bermingham E, Scott ME, Rovira JR, Conn JE 2008. Species composition and distribution of adult Anopheles (Diptera: Culicidae) in Panama. J Med Entomol 45: 841-851.

Mantilla G, Oliveros H, Barnston AG 2009. The role of ENSO in understanding changes in Colombia's annual malaria burden by region, 1960-2006. Malar J 8: 6.

Marrelli MT, Floeter-Winter LM, Malafronte RS, Tadei WP, Lourenço-de-Oliveira R, Flores-Mendoza C, Marinotti O 2005. Amazonian malaria vector anopheline relationships interpreted from ITS2 rDNA sequences. Med Vet Entomol 19: 208-218.

Mirabello L, Conn JE 2008. Population analysis using the nuclear white gene detects Pliocene/Pleistocene lineage divergence within Anopheles nuneztovari in South America. Med Vet Entomol 22: 109-119.

Moreno JE, Rubio-Palis Y, Páez E, Pérez E, Sánchez V 2007. Abundance, biting behaviour and parous rate of anopheline mosquito species in relation to malaria incidence in gold-mining areas of Southern Venezuela. Med Vet Entomol 21: 339-349.

Moreno JE, Rubio-Palis Y, Paez E, Perez E, Sanchez V, Vaccari E
2005. Anopheles (Anopheles) neomaculipalpus: a new malaria vector in the Amazon basin? Med Vet Entomol 19: 329-332.

Olano VA, Brochero H, Sáenz R, Quiñones M, Molina J 2001. Mapas preliminares de la distribución de especies de Anopheles vectores de malaria en Colombia. Biomedica 21: 402-408.

Olano V, Carrasquilla G, Mendez F 1997. Transmission of urban malaria in Buenaventura, Colombia: entomological features. Rev Panam Salud Publica 1: 287-294.

OPS/OMS - Organización Panamericana de la Salud/Organización Mundial de la Salud 2006. EPIDAT: Programa para análisis epidemiológicos de datos tabulados, versión 3.1. Dirección Xeral de Saúde Pública da Consellería de Sanidade (Xunta de Galicia), Unidad de Análisis de Salud y Sistemas de Información Sanitaria da Organización Panamericana de la Salud. Available from: http://dxsp.sergas.es/ApliEdatos/Epidat/Ayuda/Ayudageneral/ Ayuda\%20General.pdf.

Parra-Henao G, Alarcon E 2008. Observaciones sobre la bionomía de Anopheles spp (Diptera: Culicidae) en el municipio Valencia, departamento Córdoba, Colombia. Bol Mal Salud Amb 48: 95-98.

Poveda G, Rojas W, Quiñones M, Vélez I, Mantilla R, Ruiz D, Zuluaga J, Rua G 2001. Coupling between annual and ENSO timescales in the malaria-climate association in Colombia. Environ Health Perspect 109: 489-493.

Póvoa MM, de Souza RT, Lacerda RN, Rosa ES, Galiza D, de Souza JR, Wirtz RA, Schlichting CD, Conn JE 2006. The importance of Anopheles albitarsis E and An. darlingi in human malaria transmission in Boa Vista, state of Roraima, Brazil. Mem Inst Oswaldo Cruz 101: 163-168.

Quiñones ML, Ruiz F, Calle DA, Harbach RE, Erazo HF, Linton YM 2006. Incrimination of Anopheles (Nyssorhynchus) rangeli and An. (Nys.) oswaldoi as natural vectors of Plasmodium vivax in Southern Colombia. Mem Inst Oswaldo Cruz 101: 617-623.

Rodriguez MH, Gonzalez-Ceron L, Hernandez JE, Nettel JA, Villarreal C, Kain KC, Wirtz RA 2000. Different prevalences of Plasmodium vivax phenotypes VK210 and VK247 associated with the distribution of Anopheles albimanus and Anopheles pseudopunctipennis in Mexico. Am J Trop Med Hyg 62: 122-127.

Rubio-Palis Y, Zimmerman RH 1997. Ecoregional classification of malaria vectors in the neotropics. J Med Entomol 34: 499-510.

Ruiz F, Quinones ML, Erazo HF, Calle DA, Alzate JF, Linton YM 2005. Molecular differentiation of Anopheles (Nyssorhynchus) benarrochi and An. (N.) oswaldoi from Southern Colombia. Mem Inst Oswaldo Cruz 100: 155-160.

SEM - Sistema de Erradicacion de la Malaria 1957. Plan para la erradicación de la malaria en Colombia, Republica de Colombia, Ministerio de Salud Publica y Oficina Sanitaria Panamericana, Oficina Regional de la Organizacion Mundial de la Salud, Vol II, Bogotá, 635 pp.

Silva-Do-Nascimento TF, Wilkerson RC, Lourenço-de-Oliveira R, Monteiro FA 2006. Molecular confirmation of the specific status of Anopheles halophylus (Diptera: Culicidae) and evidence of a new cryptic species within An. triannulatus in Central Brazil. J Med Entomol 43: 455-459.

Singh B, Bobogare A, Cox-Singh J, Snounou G, Abdullah MS, Rahman HA 1999. A genus- and species-specific nested polymerase chain reaction malaria detection assay for epidemiologic studies. Am J Trop Med Hyg 60: 687-692.

Tadei W, Thatcher B, Santos J, Scarpassa V, Rodrigues I, Rafael M 1998. Ecologic observations on anopheline vectors of malaria in the Brazilian Amazon. Am J Trop Med Hyg 59: 325-335. 
WHO - World Health Organization 2006. Malaria vector control and personal protection, WHO, Geneva, $61 \mathrm{pp}$.

WHO - World Health Organization 2008. World Malaria Report 2008, WHO Library Cataloguing-in-Publication Data, Geneva, 215 pp.

Wilkerson RC, Parsons TJ, Klein TA, Gaffigan TV, Bergo E, Consolim J 1995. Diagnosis by random amplified polymorphic DNA polymerase chain reaction of four cryptic species related to Anopheles (Nyssorhynchus) albitarsis (Diptera: Culicidae) from Paraguay, Argentina and Brazil. J Med Entomol 32: 697-704.

Wirtz RA, Burkot TR, Graves PM, Andre RG 1987a. Field evaluation of enzyme-linked immunosorbent assays for Plasmodium falciparum and Plasmodium vivax sporozoites in mosquitoes (Diptera: Culicidae) from Papua New Guinea. J Med Entomol 24: 433-437.

Wirtz RA, Charoenvit Y, Burkot TR, Esser KM, Beaudoin RL, Collins WE, Andre RG 1991. Evaluation of monoclonal antibodies against Plasmodium vivax sporozoites for ELISA development. Med Vet Entomol 5: 17-22.
Wirtz RA, Sattabongkot J, Hall T, Burkot TR, Rosenberg R 1992. Development and evaluation of an enzyme-linked immunosorbent assay for Plasmodium vivax-VK247 sporozoites. J Med Entomol 29: 854-857.

Wirtz RA, Zavala F, Charoenvit Y, Campbell GH, Burkot TR, Schneider I, Esser KM, Beaudoin RL andre RG 1987b. Comparative testing of monoclonal antibodies against Plasmodium falciparum sporozoites for ELISA development. Bull World Health Organ 65: 39-45.

Wolda H, Galindo P (1981). Population fluctuations of mosquitoes in the non-seasonal tropics. Ecol Entomol 6: 99-106.

Yasuoka J, Levins R 2007. Impact of deforestation and agricultural development on anopheline ecology and malaria epidemiology. Am J Trop Med Hyg 76: 450-460.

Zapata MA, Cienfuegos AV, Quiros OI, Quinones ML, Luckhart S, Correa MM 2007. Discrimination of seven Anopheles species from San Pedro de Uraba, Antioquia, Colombia, by polymerase chain reaction-restriction fragment length polymorphism analysis of its sequences. Am J Trop Med Hyg 77: 67-72. 